\title{
Attachment Styles in Children Living in Alternative Care: A Systematic Review of the Literature
}

\author{
Manuela Garcia Quiroga1 • Catherine Hamilton-Giachritsis ${ }^{1,2}$
}

Published online: 17 December 2015

(C) The Author(s) 2015. This article is published with open access at Springerlink.com

\begin{abstract}
Background A large number of children are currently living in Alternative Care. The relationship they establish with their temporary caregivers can play a significant role in their development. However, little has been published regarding attachment with temporary Caregivers.

Objective The aim of this review is to analyse the existing published studies regarding attachment styles in children living in alternative care (Children's Homes and Foster Care). The review analyses rates of attachment styles and associated factors (including characteristics of settings, children and caregivers) in both settings.

Methods A systematic literature review was conducted searching electronic databases for peer reviewed publications in different languages. Studies considering attachment in children living in Children's Homes or Foster families at the time of the study were included.

Results Overall, 18 articles reporting 13 studies met the inclusion criteria. The results are presented in terms of characteristics of the studies, rates of attachment in different settings and possible mediating factors. Implications for practice and research are discussed.

Conclusions Attachment styles in children living in alternative care differ from those observed in children living with biological or adoptive families, however several factors can mediate this outcome (including characteristics of settings, children and caregivers). Most research has been conducted in Europe and USA. Therefore, further research is needed in less developed countries in order to guide local policies for better care.
\end{abstract}

Keywords Attachment · Alternative Care - Institution · Foster care · Children's Homes · Caregivers

Manuela Garcia Quiroga

psmanuelagarcia@gmail.com

School of Psychology, University of Birmingham, Edgbaston, Birmingham B15 2TT, UK

2 Present Address: Department of Psychology, University of Bath, Claverton Down, Bath BA2 7AY, UK 


\section{Introduction}

The importance of Attachment in children's development has been widely studied and there is strong evidence about the impact of the relationship a child establishes with his primary caregivers on different developmental areas (i.e., cognitive, physical, emotional and social; Main et al. 1985; Sroufe 2005). Whilst the study of attachment was initially centred on the mother-child bond (Bowlby 1979), it was later developed to include the concept of multiple attachments, such as with the father, kin and day carers (Rutter et al. 2007; Santelices and Pérez 2013). This is particularly important to consider for orphans, abandoned children and those who are removed from their families for protection or other reasons (such as poverty, gender, disability or age of mother in different countries) and are taken into some form of 'Alternative Care' (AC) - either in Children's Homes or foster families. The relationship that these children establish with their temporary caregivers has the potential to perpetuate or change previous attachment patterns. Yet, despite the importance of these relationships, only more recently have studies in attachment considered samples of children living in Children's Homes or foster families when the studies were conducted. Given the likely impact of these relationships with Caregivers, having a clear understanding of these attachments and the factors that might impact upon them seems to be very important.

\section{Alternative Care}

As well as those children without parents, an important number of children around the world have been removed from their families for several reasons, often for protection but also sometimes due to social or economic factors (E. C. Daphne Programme 2005). These children may be placed in Children's Homes or foster families for different lengths of time before being adopted, returned to their biological families or even staying in Alternative Care until they reach adulthood.

The negative impact of institutional care on future development has been widely studied, with this impact shown to be stronger in the first 3 years of life (see HamiltonGiachritsis and Garcia Quiroga 2014, for an overview of Institutional care). International recommendations on AC (United Nations, Guidelines for the Alternative Care of Children 2009) highlight the need to close institutions and develop foster care programs. However, whilst this process has begun in many countries, the implementation has been complex and several studies have revealed important difficulties with the placement of children in foster care, such as lack of motivation to foster due to cultural reasons, difficulties in supervision and support for foster parents leading to breakdowns and instability in placements and the overwhelmed foster care systems (Maluccio et al. 2006; Mapp 2011; UNICEF 2010).

Whilst in an ideal world institutional care would be phased out entirely, worldwide rates of child family maltreatment, street children and those being exploited, combined with children orphaned due to wars, natural disasters and health epidemics makes it difficult to find good quality family care for every child. Thus, the most probable scenario is that Children's Homes will continue to exist in some form and it is very important that the environment to which children and youth are moved is significantly better that the environment from which they are removed. Although good quality and stable foster care would be preferred and should continue to be strived for, in the absence of these, protection needs to be effectively provided by good quality Children's Homes, utilising research knowledge about how to make these environments as conducive to good child development as 
possible. For example, despite a lot of negative outcomes for children living in institutional care being identified in Europe (Johnson et al. 2006), in other parts of the world, children and young people have been shown to have good outcomes following institutional care. One study conducted in five less wealthy nations described no differences in health, emotional/cognitive functioning and physical growth outcomes for Orphans and Abandoned children living in institutional and community-based care (Whetten and the POFO Research Team 2009). Alongside other factors that might impact, it is useful to consider the role of attachment with alternative carers and the impact on likely prognosis and development.

\section{Attachment in Alternative Care}

The relationship that children living in alternative care establish with their temporary caregivers has the potential to either perpetuate or change the previous patterns of attachment the child had built up with prior caregivers (biological parents or other previous placements). In alternative care, children also need to process their losses and previous traumatic experiences; thus, an adequate and sensible caregiver can become a secure base to the child in order to build up a relationship that can help in this process. Potentially, having the experience of a secure attachment can lead the way to future positive attachments with adoptive or biological parents. Yet attachment between the child and the caregiver is often discouraged as a way to "protect" the children from the pain of future separations, thereby limiting the possibility of change in the internal working models of these children.

In 1999, Smyke, Dumitrescu and Zeanah conducted a study in a Romanian institution with three groups: (a) a 'typical' unit; (b) a pilot unit with fewer adults caring for each child, giving greater stability in care; and (c) a control group of never institutionalised children. They found significantly higher rates of Reactive Attachment Disorder (RAD) in children in the typical unit than in the other two groups. Notably, children described as 'their favourite' by a caregiver had lower rates of attachment disorders (Smyke et al. 2002).

On a positive note, the St. Petersburg-USA Orphanage Intervention Study (2008) found that improvements in institutional care can have a significant impact on a wide range of areas of development, including child-caregiver relationship and attachment. An intervention based on structural changes (smaller groups and fewer changes of caregivers) and training (with a socio-emotional perspective) proved to have a wide impact on children's' development. Similarly, two intervention studies in Latin America found that staff training led to an improvement in caregiver-child interactions, with warmer and sensitive response impacting positively on children's development (Lecannelier et al. 2014; McCall et al. 2010). Hence, the importance of child-caregiver interactions is clear.

An interesting review by Bakermans-Kranenburg et al. (2011) looked at attachment and emotional development in institutional care, and included studies both with children living in institutions and post adoption studies. The authors underlined the importance of considering some specifics when studying attachment in these contexts. In particular, they highlighted the need to take into account the possible lack of a specific attachment in some children reared in institutions due to limitations in developing a stable relationship with a specific Caregiver, where this lack of attachment formation can be misunderstood as disorganised attachment (e.g., with the Strange Situation Procedure. They propose the use of an attachment formation rating scale in these context. The review also discusses the concept of indiscriminate friendliness, and the nature of it in institutional settings, stating that it may respond to different factors than those observed in family contexts. The authors 
highlight the need for further study considering quality of care at the micro caring environment.

However, although the Bakermans-Kranenburg et al. (2011) review did include some important studies of children within institutions, its main focus was the analysis of methodological issues regarding the assessment of attachment disorders, indiscriminate friendliness and attachment formation in these settings, as well as the development of attachment following adoption. Thus, it did not analyse rates of attachment styles found in studies conducted while children were still living in residential settings, and it includes both studies of institutionalised and post adoption children but no study of foster care. Its main aim was to discuss emotional development in institutional care or post adoption.

In summary, little has been published regarding studies with a focus on rates of attachment styles (secure, avoidant, anxious and disorganised) in children living with their temporary caregivers at the time of the study. Temporary (paid) caregivers are likely to differ significantly to those who chose to adopt a child from an institution, but have a key role to play in enabling a child's recovery. In summary, the fact that most studies and reviews include post-adoption samples as well as children living in institutions makes it difficult to describe the specific relationship children establish with their temporary caregivers, as opposed to adoptive parents.

\section{Objectives}

Therefore, this review aims to describe and analyse the research that has been published regarding studies of attachment styles with children living in foster care or Children's Homes. It is the first review with a focus on attachment to temporary caregivers exclusively considering studies of attachment styles with children living in alternative care at the time of the study. Specifically, a comparison between two different types of AC settings (Institutional and Foster Care) is made. This is considered an important point as many countries are moving from institutional care to foster care. The review includes rates of attachment and aims to provide an integrated analysis of different factors affecting the quality of attachment with caregivers in AC settings. It also provides a critical review of methodological issues and suggestions about future research on this topic. This review considers studies conducted from 1987 to 2013, in order to evaluate developments in the research. The specific hypotheses to be considered were:

1. There will be differences in the attachment styles of children living in biological families, institutional and foster care respectively.

2. Children living in foster care will have more positive attachment representations compared to children still living in institutional care.

3. In both institutional settings and foster homes, the quality of attachment (i.e., security) will be related to a number of mediating factors, including higher sensitivity of caregiver, higher quality of caregiving, younger age at placement and motivations of caregiver.

4. There will be differences between countries and between different types of institutions and foster care programs, regarding rates of attachment styles.

5. Methodological challenges in the study of attachment in alternative care contexts will also be reviewed. 


\section{Method}

\section{Design}

A standard Systematic Literature Review methodology was employed. This included a search strategy based on inclusion and exclusion criteria according to population, exposure, comparator and outcomes (PECO), followed by Quality Assessment (QA) according to the type of study (case-control, cross sectional, randomised control trial or longitudinal). QA criteria looked for selection bias, performance and assessment bias, and attribution bias (coding strategy: yes $=2$, partly $=1$ and no $=0$ ). When the item was coded as unsure, more information was searched for (i.e., additional information not reported in the articles but stated in other publications and contacts with the authors when possible), to gain the final QA score.

\section{Search Strategy}

The search of published articles was conducted with different databases (PsycInfo 1987-2013, Medline 1996-2013, Web of Science, ASSIA, Scielo, ChildLink!, Embase 1996-2013). The following search terms (with appropriate Booleans and truncations, plus English and American spellings) were used: attachment, attachment behaviour, attachment theory, attachment disorders, attachment style, attachment representations, bonding, foster children, foster care, foster parents, alternative care, out of home care, residential care, institutional care, abandoned children, children's homes, family-type home and orphanages.

Different languages were included in the search (English, French, Portuguese and Spanish articles were considered). Experts were contacted for suggestion on relevant articles in the topic. In addition, a search for grey literature on the web was conducted and the reference lists of relevant articles were hand checked. The inclusion criteria considered:

- Population: Children aged 0-17 years

- Exposure: Children living in alternative care (institutions and foster families) at the time of the study for a minimum of 2 months.

- Comparator: General population 0-17 or no comparison group.

- Outcome: Measures of attachment styles in children living in Alternative Care.

The exclusion criteria were: studies of adoption, studies of adulthood after AC, studies of specific psychopathologies (i.e., Autism, special needs, developmental problems, prenatal exposure to drugs), studies of children previously institutionalised or fostered but then with adoptive or birth families, studies measuring attachment only in carers and studies that evaluate the impact of specific interventions (other than when the intervention is placement in a Foster Care Program). This review focused on empirical papers, therefore well-known reviews were not included (e.g., van den Dries et al. 2009).

This search generated a total of 634 articles. Following the inclusion criteria and after removing duplicates, 147 articles remained based on the title. A further 112 were excluded based on the abstract, leaving 35 to be read in full, of which 17 were excluded. Thus, 18 articles were selected for the literature review, which reported on data from 13 studies.

\section{Quality Assessment and Inter-Rater Reliability}

All the articles had a QA score of $50 \%$ or more, with the majority of them having $70 \%$ or more. A decision was made to include all of them in the review in order to better represent 
all the different studies in the topic and to be able to give a more culturally diverse view of existing research. For inter-rater reliability, $20 \%$ of the articles were double coded (cronbach alpha $=.967$ ); differences between coders were discussed and a consensus reached.

\section{Ethics Statement}

This study does not include primary data, thus, no ethics approval was applicable. There are no conflict of interest present in this review.

\section{Conflict of Interest}

The authors have no conflict of interest.

\section{Access to Data}

The first author takes responsibility for the integrity of the data and the accuracy of the data evaluation and analysis.

\section{Results}

\section{Description of the Studies}

The 18 articles reviewed were based on 13 studies. Two studies (The Bucharest Early Intervention Project [BEIP] and Cole) were reported in several different articles considering different topics with the same sample, sub-samples or at follow-up (see Table 1). The location of the studies varies; five of the 13 studies were conducted in the USA, four in European countries (France, ${ }^{1}$ Greece, Romania and Ukraine), two in Asia (Japan and Israel), one in Canada and one in Africa (D. R. Congo). None of the data of children living in AC (institutions or foster families) was collected in Latin America. Regarding the settings, six studies were conducted with children living in institutions and six of them with children living in Foster Care. Only one study considered samples in both institutions and foster care (McLaughlin et al. 2012) and, in that case, the Foster Care program was especially designed for the study.

More than half of the studies $(n=7)$ had a cross sectional design, four were casecontrol comparing institutionalised with family raised children, only one used a randomised control trial design (BEIP) and only one had a longitudinal design (Bernier et al. 2004).

Children's ages varied widely across the studies (6 months-18 years old) making the results difficult to compare. More than half had samples with children younger than 36 months $(\mathrm{n}=8)$, yet no study had exactly the same age range as another. Four other studies had samples of 3-7 year olds with little variation between them, and two considered older children (one 6-14 years; one adolescent sample).

The measures of attachment also varied widely, as expected given the variation in ages. Half of the studies used the Strange Situation Procedure (SSP, Ainsworth et al. 1978), but

1 This study considered a comparison sample of adopted children in Chile but all of the children in the alternative group lived in France Eulliet et al. (2008). 


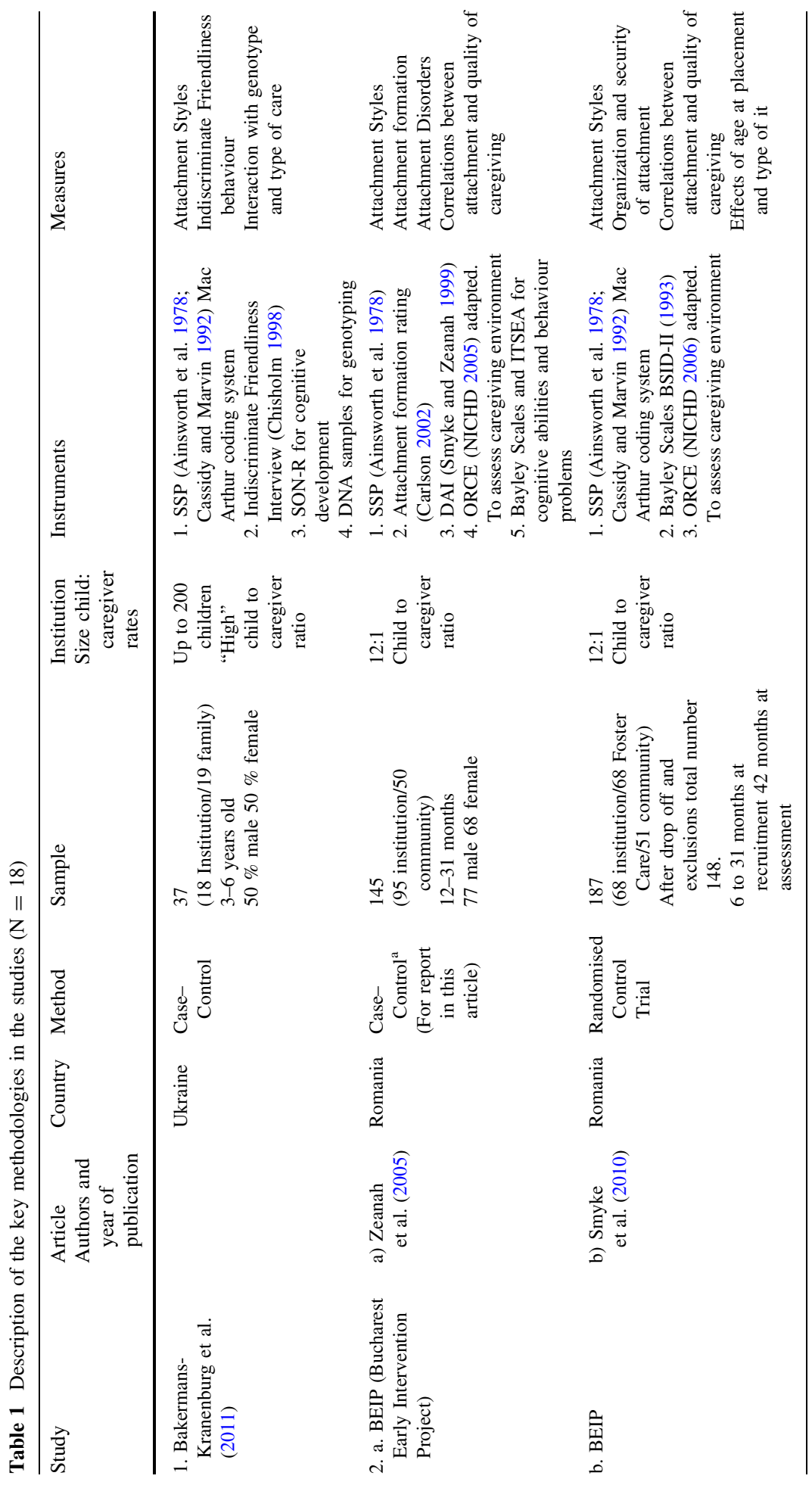




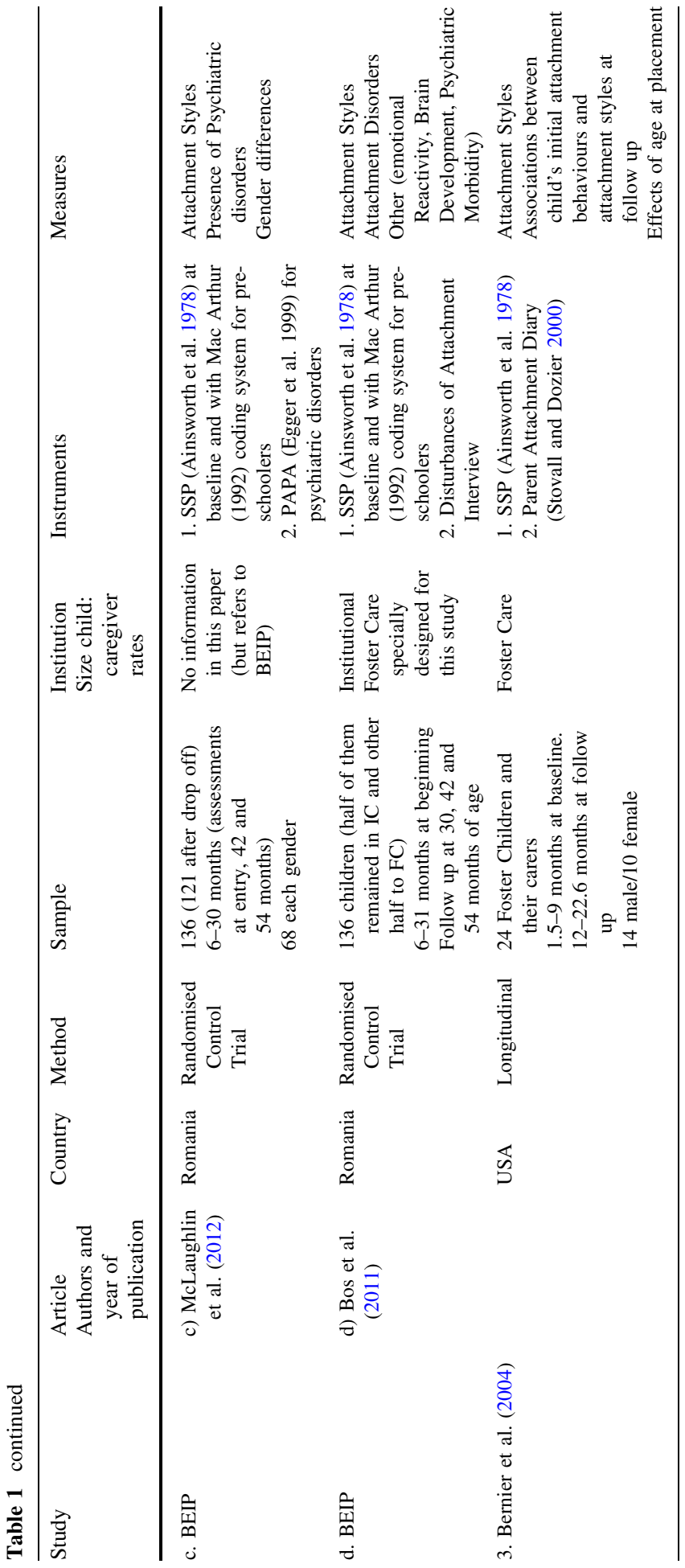




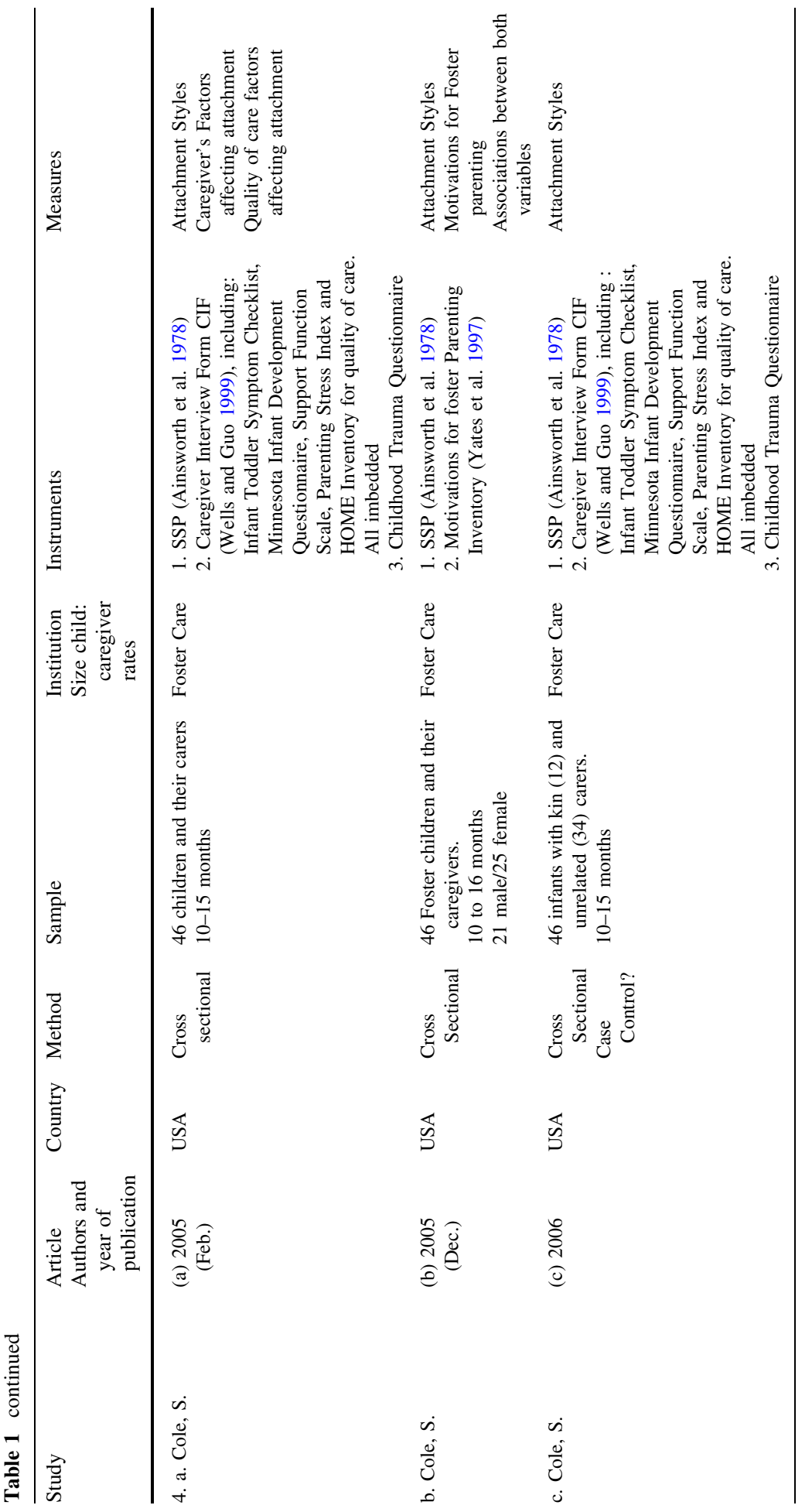




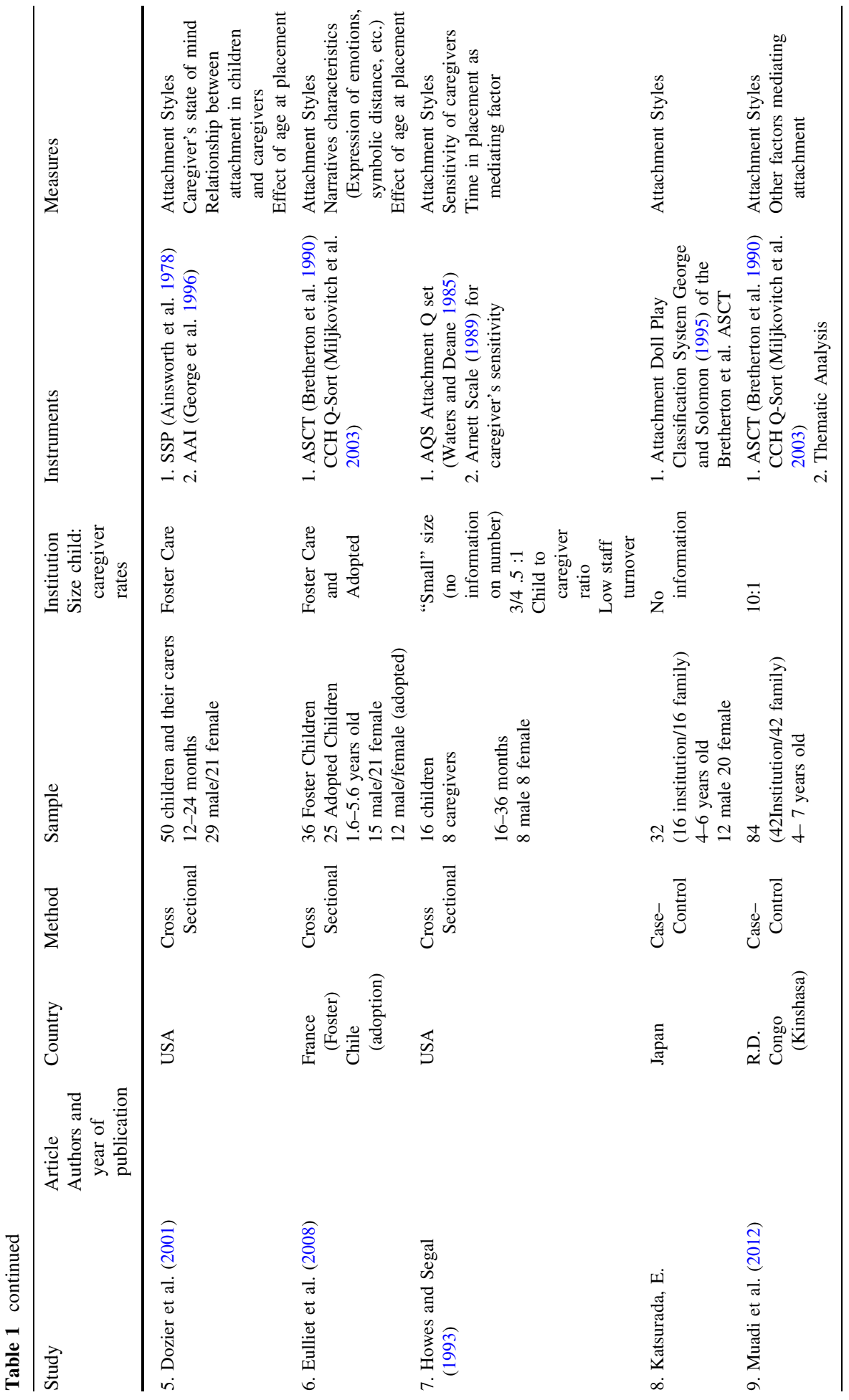




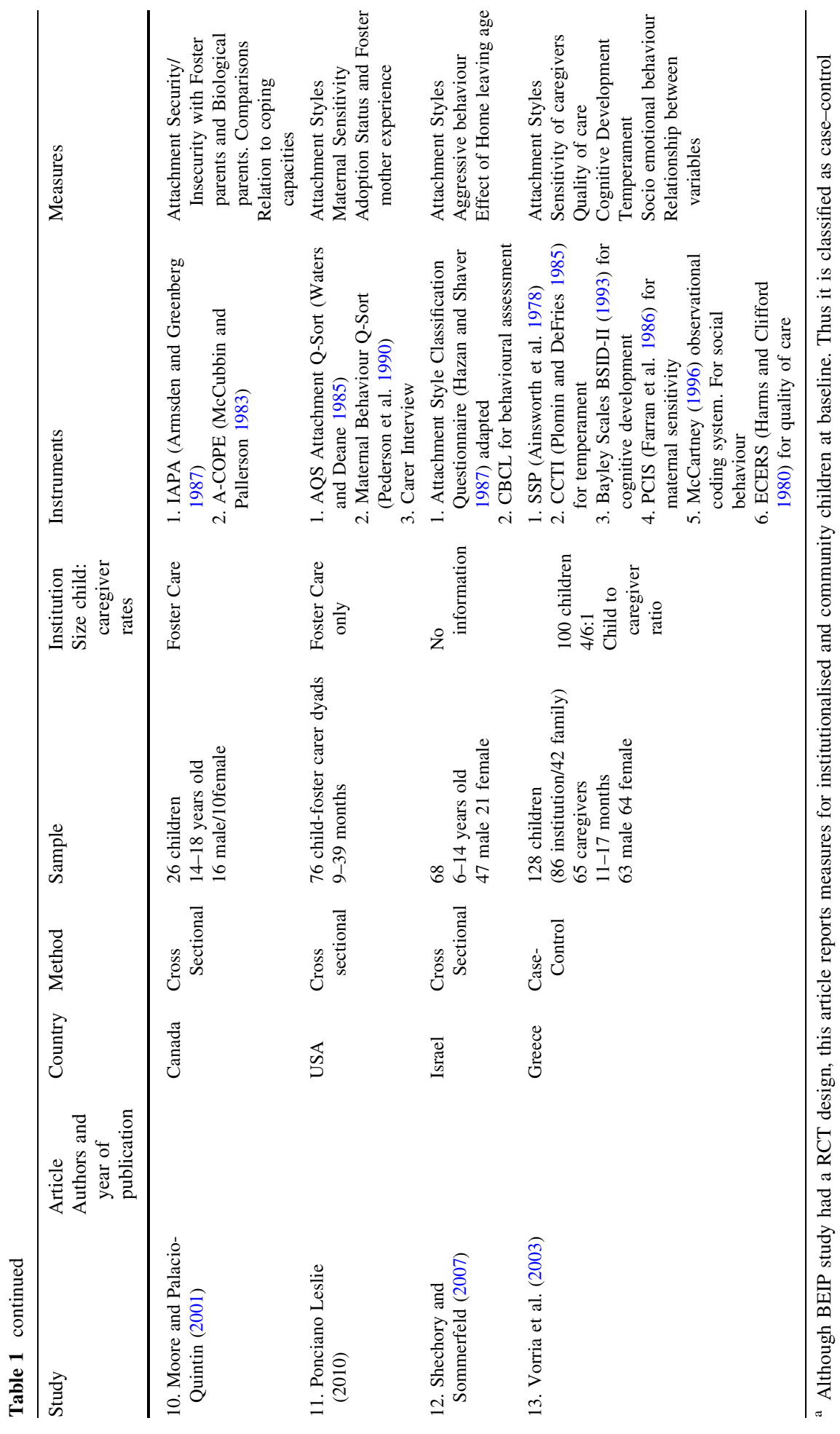


with different coding systems according to the age of the sample. Three studies used the Attachment Story Completion Task (ASCT; Bretherton et al. 1990), but one of the three considered only three of the stories (George and Solomon 1995). A further two studies used the AQS (Waters and Deane 1985) and the remaining two studies used different measures (Table 1).

All the studies reported results in terms of rates, percentage or number of children classified in the different Attachment Styles (as this was considered an inclusion criteria). However, studies varied in the number of categories considered, with some of them reporting only secure/insecure rates, while others considered the distribution across the four main categories ABCD (Avoidant, Secure, Anxious-ambivalent and Disorganised). Most of the studies describe some factors affecting attachment, such as age at placement, type of placement, characteristics of the caregivers (motivation, sensitivity, state of mind, childhood trauma), genetic mediators, and quality of caregiving. Some studies include measures in other areas (i.e., cognitive development, psychiatric morbidity).

\section{Overview of Findings}

For a summary of main findings in each study plus reports on the limitations and Quality Scores (QA), see Table 2, with specific rates of attachment styles listed in Table 3 (institutional care) and Table 4 (foster care).

\section{Attachment Styles in Institutional Care}

Overall, the distributions of the different attachment styles in children living in institutions have been shown to have lower rates of secure and higher rates of disorganised attachment than those observed in children living with their biological parents in the general population (Bakermans-Kranenburg et al. 2011; Katsurada 2007; Muadi et al. 2012; Zeanah et al. 2005). Table 3 summarises the distribution of attachment styles in the eight papers reporting seven studies of children living in institutions. Results show wide differences between studies, the mean rate of secure attachment was $26 \%$ (median $=25.9$, range 0-47 \%), avoidant $23 \%$ (median $=24.8$, range $2.5-55.5 \%$ ), ambivalent $11.8 \%$ (median $=10.6$, range $0-26 \%$ ) and disorganised $43.6 \%$ (median $=48.6$, range 5.3-65.8 \%). The high rates of disorganised attachment in children living in institutions may be a response to conditions that hinder the construction of an organised attachment. As suggested by some authors, the disorganisation in attachment patterns in these settings may not reflect the same processes as in family settings (where parental abuse or a carer's unresolved status due to loss or trauma may be the key). In institutions, disorganised attachment may just reflect the lack of opportunity for the formation of an organised attachment due to the limited resources, such as single caregiver for many children, the shift system and staff changes (Bakermans-Kranenburg et al. 2011).

The Howes and Segal (1993) study found higher rates of attachment security compared to other studies. Notably, the institution in this study appeared to be of good quality and stability of caregiving (good child: caregiver ratio, low staff turn-over, small size), which may explain the higher secure attachment. This is consistent with results shown in the main intervention study, conducted by St. Petersburg-USA intervention project (2008). It also reflects the fact that institutions can vary widely in their quality of care and that these variations can have a strong impact on emotional development and attachment. Thus, not all institutions are the same and have the same outcomes. 
Table 2 Main findings regarding attachment, limitations and QA

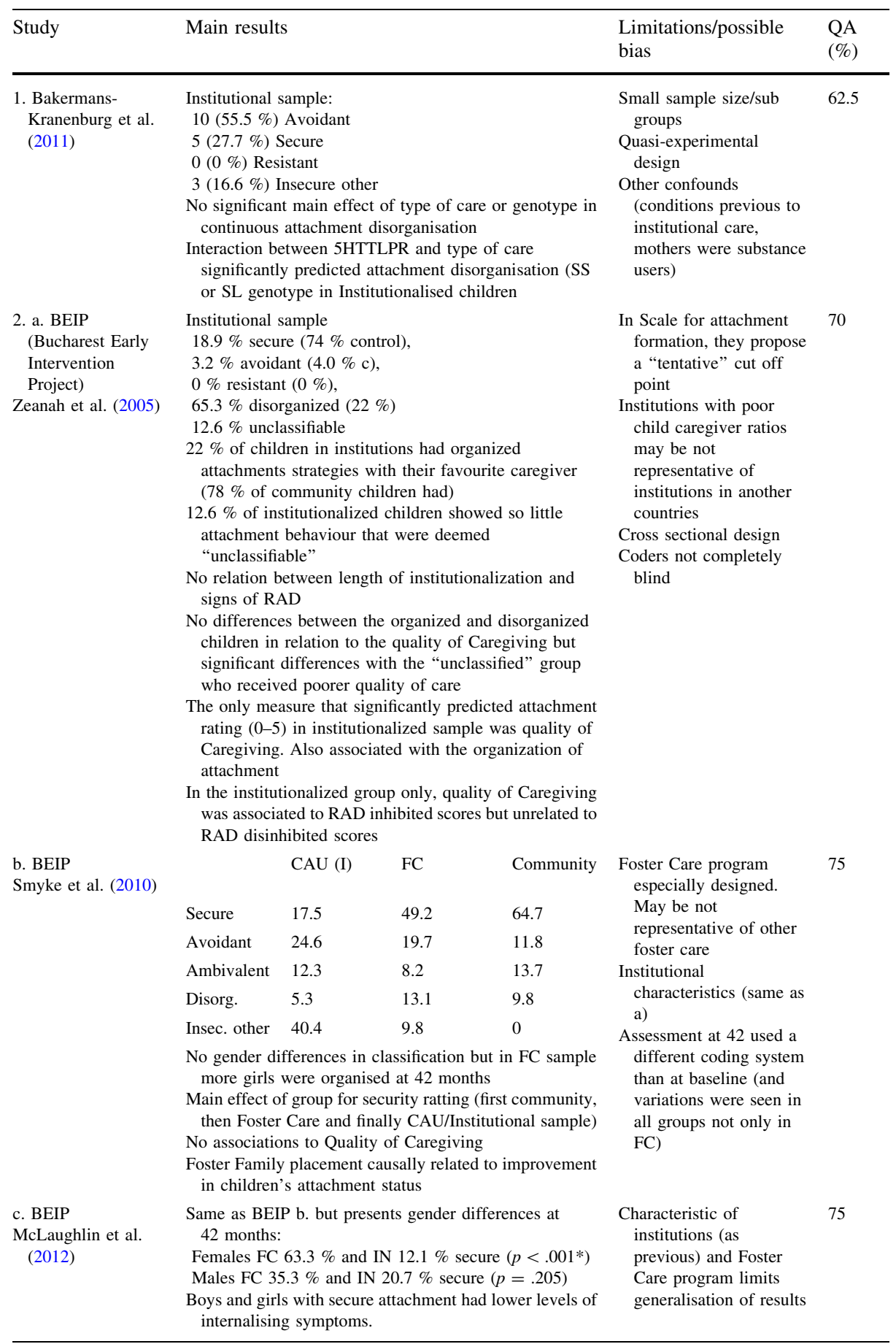


Table 2 continued

\begin{tabular}{|c|c|c|c|}
\hline Study & Main results & $\begin{array}{l}\text { Limitations/possible } \\
\text { bias }\end{array}$ & QA $(\%)$ \\
\hline $\begin{array}{l}\text { b. Cole, S. } \\
2005 \text { (Dec.) }\end{array}$ & $\begin{array}{l}\text { Attachment in Foster Care (same as reported in previous } \\
\text { article a), same sample). } \\
\text { Foster Caregiver's Motivations are related to Infant's } \\
\text { Attachment: } \\
\text { Positive predictors for secure attachment were: Desire } \\
\text { to increase family size (significant } p=.031 \text { ) and } \\
\text { social concern for caregiver's specific community } \\
\text { Predictors for Insecure attachment were: spiritual } \\
\text { expression, desire of adoption and replacement of a } \\
\text { grown child }\end{array}$ & $\begin{array}{l}\text { Self-selected sample (as } \\
\text { previous) } \\
\text { Retrospective design } \\
\text { (memory about initial } \\
\text { motivations can } \\
\text { change) }\end{array}$ & 72.7 \\
\hline
\end{tabular}


Table 2 continued

\begin{tabular}{llll}
\hline Study & Main results & $\begin{array}{l}\text { Limitations/possible } \\
\text { bias }\end{array}$ & QA (\%) \\
\hline
\end{tabular}

c. Cole, $\mathrm{S}$. 2006

5. Dozier et al. (2001)

6. Eulliet et al. (2008)

7. Howes and Segal (1993)
Attachment in Foster Care (same as reported in a) but analysed differences between kin and unrelated FC:

$\begin{array}{lll} & \text { Kin }(\%) & \text { Unrelated (\%) } \\ \text { Secure } & 67 & 68 \\ \text { Insecure } & 8 & 3 \\ \text { Disorganised } & 25 & 28\end{array}$

Attachment in Foster Care:

$52 \%$ Secure

$6 \%$ Avoidant

$8 \%$ Resistant

$34 \%$ Disorganised

Significant association between caregiver's state of mind and infant attachment

Non autonomous and dismissing Foster Mothers tended

to have children with disorganised attachment

Secure/Autonomous Foster Mothers tended to have secure children

Attachment in Foster Care:

$69.4 \%$ Secure

$30.6 \%$ Avoidant

$0 \%$ Hyper activated

$0 \%$ Disorganised

No main effect of age at placement

Attachment in Institutional Care:

$47 \%$ Secure

$44 \%$ Avoidant

$9 \%$ Ambivalent

(No measure of disorganised)

Security in attachment associated with sensitivity of Caregiver

Length of placement positive association with security of attachment $(p<.01)$

(Institution with indicators of good quality of care)
Potential impact of uneven sample size $(\mathrm{n}=12, \mathrm{n}=34)$

Small sub group sample sizes

Older children assessed with SSP (but separate analysis were conducted)

Relatively small sample size

Small sample size

No information about sample method

No information about double coding or blindness of coders to child status

Small sample size

$63 \% @$

Majority of children in sample had previous placements

No double coding for children in the study 
Table 2 continued

\begin{tabular}{|c|c|c|c|c|c|}
\hline \multirow{2}{*}{$\begin{array}{l}\text { Study } \\
\text { 8. Katsurada, E. }\end{array}$} & \multicolumn{3}{|l|}{ Main results } & \multirow{3}{*}{$\begin{array}{l}\text { Limitations/possible } \\
\text { bias } \\
\begin{array}{l}\text { Small sample and sub } \\
\text { groups }\end{array} \\
\text { Sample method not } \\
\text { clearly stated }\end{array}$} & QA $(\%)$ \\
\hline & \multicolumn{3}{|l|}{ Attachment in: } & & $50 \%$ \\
\hline & & $(\%)$ & rammiy reared (\%) & & \\
\hline & Secure & 0 & 31.3 & No double coding, no IIR & \\
\hline & Avoidant & 25 & 12.5 & Information about the & \\
\hline & Ambivalent & 25 & 25.0 & measure used is not & \\
\hline & Disorganised & 50 & 31.3 & $\begin{array}{l}\text { In FR sample the high } \\
\text { percentage of } \\
\text { disorganised (refused to } \\
\text { elaborate a story) could } \\
\text { be related to confound } \\
\text { factors in assessment }\end{array}$ & \\
\hline \multirow[t]{6}{*}{$\begin{array}{l}\text { 9. Muadi et al. } \\
\text { (2012) }\end{array}$} & Attachment in: & $\begin{array}{l}\text { Institution } \\
(\%)\end{array}$ & Control (\%) & $\begin{array}{l}\text { No detailed information } \\
\text { about sampling method } \\
\text { and drop out }\end{array}$ & 62.5 \\
\hline & Secure & 33.3 & 66.7 & $\begin{array}{l}\text { No information about } \\
\text { institution beyond the }\end{array}$ & \\
\hline & Insecure Avoidant & 4.7 & 4.7 & fact that there are one of & \\
\hline & $\begin{array}{l}\text { Insecure } \\
\text { Ambivalent }\end{array}$ & 14.3 & 16.6 & the "best reputed" & \\
\hline & Disorganised & 47.6 & 11.9 & & \\
\hline & \multicolumn{5}{|c|}{$\begin{array}{l}\text { A factor of Resilience that can promote secure } \\
\text { attachment is the establishment of a significant } \\
\text { relationship }\end{array}$} \\
\hline $\begin{array}{l}\text { 10. Moore and } \\
\text { Palacio-Quintin } \\
\text { (2001) }\end{array}$ & \multicolumn{3}{|c|}{$\begin{array}{l}\text { Attachment in Foster Care to multiple figures } 55.5 \% \\
\text { Secure with Foster Mother ( } \mathrm{n}=10 \text { out of } 18) \\
45.5 \% \text { Insecure with Foster Mother }(\mathrm{n}=8 \text { of } 18) \\
63.1 \% \text { Secure with Biological Mother }(\mathrm{n}=12 \text { of } 19) \\
36.8 \% \text { Insecure with Biological Mother }(\mathrm{n}=7 \text { of } 19) \\
\text { Attachment to fathers was less secure than attachment to } \\
\text { mothers with both biological and foster figures } \\
\text { Attachment with mothers was more secure with the } \\
\text { biological mother and attachment with father was more } \\
\text { secure with the foster figure. However other data } \\
\text { presents more positive representations of Foster } \\
\text { mothers in comparison to biological parents } \\
6 \text { Adolescents had the same patterns with biological and } \\
\text { foster figures and } 8 \text { changed their patterns ( } 2 \text { of them } \\
\text { building more secure ones with Foster Care and } 4 \text { of } \\
\text { them more insecure ones) } \\
\text { Security in attachment correlates with coping capacity }\end{array}$} & $\begin{array}{l}\text { Small sample size } \\
\text { Sample characterised by } \\
\text { having regular contact } \\
\text { with biological parents, } \\
\text { this limits } \\
\text { generalisation } \\
\text { Evaluation of attachment } \\
\text { representations only } \\
\text { based in the } \\
\text { Adolescent's report in a } \\
\text { Likert scale } \\
\text { All information processed } \\
\text { by researcher no inter } \\
\text { reliability } \\
\text { Rates of attachment not } \\
\text { clearly presented and } \\
\text { contradictory } \\
\text { information }\end{array}$ & $50 \%$ \\
\hline
\end{tabular}


Table 2 continued

\begin{tabular}{|c|c|c|c|c|c|}
\hline Study & \multicolumn{3}{|l|}{ Main results } & $\begin{array}{l}\text { Limitations/possible } \\
\text { bias }\end{array}$ & QA (\%) \\
\hline $\begin{array}{l}\text { 11. Ponciano Leslie } \\
\text { (2010) }\end{array}$ & \multicolumn{3}{|c|}{$\begin{array}{l}\text { Attachment in Foster Care: } \\
58 \% \text { Secure } \\
11 \% \text { Avoidant } \\
9 \% \text { Ambivalent/Resistant } \\
22 \% \text { Unclassifiable } \\
\text { Maternal Sensitivity: More sensitive FC had more } \\
\text { securely attached children } \\
\text { Less experienced Foster Mothers tended to have more } \\
\text { securely attached children } \\
\text { Security in attachment was higher in those children } \\
\text { whose FC had decided to adopt them } \\
\text { Number of children in Care in same house negatively } \\
\text { related to attachment security } \\
\text { Age was inversely correlated with attachment security } \\
\text { Visit from the biological parents were inversely } \\
\text { correlated with attachment security }\end{array}$} & $\begin{array}{l}\text { No information about } \\
\text { parents that declined } \\
\text { participation (self- } \\
\text { selection) } \\
\text { All measures coded by } \\
\text { researcher } \\
\text { Most measures based in } \\
\text { Foster carer's } \\
\text { perceptions }\end{array}$ & 86 \\
\hline $\begin{array}{l}\text { 12. Shechory and } \\
\text { Sommerfeld } \\
\text { (2007) }\end{array}$ & \multicolumn{3}{|c|}{$\begin{array}{l}\text { Attachment in Institutional Care: } \\
39.7 \% \text { Secure } \\
25.0 \% \text { Avoidant } \\
26.5 \% \text { Anxious/Ambivalent } \\
9 \% \text { Unclassified } \\
\text { Main effect of attachment style in Anxiety/Depression } \\
\text { scale } \\
\text { The aggression levels were higher for children removed } \\
\text { before } 7 \text { years old with an insecure attachment but } \\
\text { lower for children removed at same age but with } \\
\text { secure attachment }\end{array}$} & $\begin{array}{l}\text { Only one institution } \\
\text { No information about } \\
\text { quality of care provided } \\
\text { or characteristics of the } \\
\text { institution } \\
\text { Sample with majority of } \\
\text { children with Attention } \\
\text { deficit disorder or } \\
\text { learning disabilities }\end{array}$ & $59 \%$ \\
\hline $\begin{array}{l}\text { 13. Vorria et al. } \\
\text { (2003) }\end{array}$ & $\begin{array}{l}\text { Secure } \\
\text { Avoidant } \\
\text { Ambivalent } \\
\text { Disorganised } \\
\text { Sensitivity in } \\
\text { between gr } \\
\text { No correlatio } \\
\text { Caregiver's }\end{array}$ & $\begin{array}{l}24.1 \\
2.5 \\
7.6 \\
65.8 \\
\text { Caregiver's was sis } \\
\text { ups in appropriate } \\
\text { between attachme } \\
\text { ensitivity or lengt }\end{array}$ & $\begin{array}{l}25.0 \\
\text { y different } \\
\text { quality } \\
\text { y and } \\
\text { tionship }\end{array}$ & $\begin{array}{l}\text { Potential impact of } \\
\text { uneven sample size } \\
(\mathrm{N}=86, \mathrm{~N}=42) \\
\text { Sample method not } \\
\text { clearly stated } \\
\text { Control sample not } \\
\text { representative of } \\
\text { general population. And } \\
\text { had low quality day } \\
\text { care } \\
\text { Moderate inter-ratter } \\
\text { reliability for SSP } \\
\text { Institution with indicators } \\
\text { of low quality of care } \\
\text { can affect } \\
\text { generalisation of results }\end{array}$ & 70.8 \\
\hline
\end{tabular}

\section{Attachment Styles in Foster Care}

In the case of foster care children (Table 4), regardless of quality, all papers except one (Eulliet et al. 2008) found that the distributions of attachment patterns are half way between institutionalised and community children when compared to control samples or general rates of attachment. The mean rate of secure attachment was $56.7 \%$ (median $=55.5$, range $45.8-69.4 \%$ ), avoidant $12.6 \%$ (median $=8.5$, range $4.2-30.6 \%)$, ambivalent $5.58 \%$ (median $=8.5$, range $0-8.3 \%$ ) and disorganised $23.3 \%$ (median $=28$, range 0-41.7 \%) (Bernier et al. 2004; Cole 2005a, b, 2006; Dozier et al. 2001; Moore and Palacio-Quintin 2001; Ponciano 2010; Smyke et al. 2010). 
Table 3 Distribution of attachment styles in children living in institutions

\begin{tabular}{|c|c|c|c|c|c|c|c|}
\hline \multirow[t]{2}{*}{ Country/Age } & \multicolumn{5}{|c|}{ Attachment style } & \multirow[t]{2}{*}{ Instrument } & \multirow{2}{*}{$\begin{array}{l}\text { QA } \\
(\%)\end{array}$} \\
\hline & Secure & Avoidant & Ambival & Disorg & Other & & \\
\hline $\begin{array}{l}\text { Greece } \\
11-17 \mathrm{~m}\end{array}$ & 24.1 & 2.5 & 7.6 & 65.8 & - & SSP & 70 \\
\hline \multicolumn{8}{|l|}{ Romania } \\
\hline (a) $12-31 \mathrm{~m}$ & 18.9 & 3.2 & $\mathbf{0}$ & 65.3 & 12.6 & $\begin{array}{l}\text { Strange Situation Procedure } \\
(\mathrm{SSP})\end{array}$ & 70 \\
\hline $\begin{array}{l}\text { (b) } 42 \mathrm{~m} \\
\text { (follow up) }\end{array}$ & 17.5 & 24.6 & 12.3 & 5.3 & 440.4 & SSP (Mac Arthur) & 775 \\
\hline $\begin{array}{l}\text { USA } \\
16-36 \mathrm{~m}\end{array}$ & 47 & 44 & 9 & - & - & $\begin{array}{l}\text { Attachment Q-Set (Waters } \\
\text { and Deane) }\end{array}$ & 63 \\
\hline $\begin{array}{l}\text { Ukraine } \\
3-6 \text { years }\end{array}$ & 27.7 & 55.5 & 0 & 27.7 & 16.6 & $\begin{array}{l}\text { SSP (Cassidy-Marvin/Mac } \\
\text { Arthur) and Scale for } \\
\text { disorganised behaviour }\end{array}$ & 62.5 \\
\hline $\begin{array}{l}\text { R.D. Congo } \\
4-7 \text { years }\end{array}$ & 33.3 & 4.7 & 14.3 & 47.6 & & $\begin{array}{l}\text { Attachment Story } \\
\text { Completion Task ASCT } \\
(\mathrm{CCH})\end{array}$ & 62.5 \\
\hline $\begin{array}{l}\text { Israel } \\
6-14 \text { years }\end{array}$ & 39.7 & 25 & 26.5 & - & 9.0 & $\begin{array}{l}\text { Attachment Style } \\
\text { Classification } \\
\text { Questionnaire (Hazan } \\
\text { Shavers) }\end{array}$ & 59 \\
\hline $\begin{array}{l}\text { Japan } \\
4-6 \text { years }\end{array}$ & 0 & 25 & 25 & 50 & - & $\begin{array}{l}\text { Attachment Doll Play-ASCT } \\
\text { (George and Solomon 1995) }\end{array}$ & 50 \\
\hline
\end{tabular}

Table 4 Distribution of attachment styles in children living in foster care

\begin{tabular}{|c|c|c|c|c|c|c|c|}
\hline \multirow{2}{*}{$\begin{array}{l}\text { Country/ } \\
\text { Age }\end{array}$} & \multicolumn{5}{|c|}{ Attachment style } & \multirow[t]{2}{*}{ Instrument } & \multirow{2}{*}{$\begin{array}{l}\text { QA } \\
(\%)\end{array}$} \\
\hline & Secure & Avoidant & Ambivalent & Disorganiz. & Other & & \\
\hline $\begin{array}{l}\text { USA } \\
9-39 \mathrm{~m}\end{array}$ & 58 & 11 & 9 & - & 22 & $\begin{array}{l}\text { Attachment Q-Sort } \\
\text { (Waters and Deane) }\end{array}$ & 86 \\
\hline $\begin{array}{l}\text { Romania } \\
42 \mathrm{~m}\end{array}$ & 49.2 & 19.7 & 8.2 & 13.1 & 9.8 & SSP (Mac Arthur) & 75 \\
\hline $\begin{array}{l}\text { USA } \\
10-15 \mathrm{~m}\end{array}$ & 67 & 4.3 & $\mathbf{0}$ & 28 & - & SSP & 75 \\
\hline $\begin{array}{l}\text { USA } \\
6-22 \mathrm{~m}\end{array}$ & 45.8 & 4.2 & 8.3 & 41.7 & - & $\begin{array}{l}\text { Parent Attachment } \\
\text { Diary/SSP }\end{array}$ & 73 \\
\hline $\begin{array}{l}\text { USA } \\
12-24 \mathrm{~m}\end{array}$ & 52 & 6 & 8 & 34 & - & SSP/AAI & 72.7 \\
\hline $\begin{array}{l}\text { France } \\
3-5 \text { years }\end{array}$ & 69.4 & 30.6 & 0 & 0 & - & ASCT $(\mathrm{CCH})$ & 62.5 \\
\hline $\begin{array}{l}\text { Canada } \\
14-18 \text { years }\end{array}$ & 55.5 & - & - & - & $\begin{array}{l}45.5 \\
\quad \text { insecure }\end{array}$ & $\begin{array}{l}\text { Inventaire } \\
\text { d'Attachement } \\
\text { Parent-Adolescent }\end{array}$ & 50 \\
\hline
\end{tabular}

Three studies appear to be particularly well suited for comparison, as they have samples of similar age and country, and used the same instrument and coding system, i.e., the SSP (Bernier et al. 2004; Cole 2005a, b, 2006; Dozier et al. 2001). Within these three studies, rates of attachment also varied (i.e., disorganised attachment ranged from 28 to $41.7 \%$ ). 
However, communication with an author revealed that two of the studies shared some of the same sample (Bernier et al. 2004; Dozier et al. 2001); notably, these two had a smaller variation, whilst the third study (Cole 2005a, b, 2006) was quite different. Therefore, the differences may well be methodological.

In summary, the studies in both institutional and foster care have been conducted with different methodologies, with large variations in age range, instruments and the categories of attachment that are included. For these reasons the results cannot always be compared. Furthermore, the levels of deprivation in different institutions and countries can also vary considerably as can the quality of foster care programs making generalisations of conclusions very difficult. Despite this, it is notable that the studies seemed to show a pattern between institutionalised (low rate of secure attachments), foster care (mid-range) and children at home (highest rate of secure attachments).

As a whole, these findings support hypotheses 1 and 2 regarding differences in attachment styles between children raised in biological families, institutions and foster care. As expected, children in institutions develop less secure and more disorganised attachments than those raised in biological families and children living with foster families show levels of security and disorganisation in between the other two groups. However, very few studies consider samples of all these three groups-so comparisons are made with children from different countries and, thus, are limited.

\section{Factors Affecting the Quality of Attachment}

Supporting hypothesis 3, some studies have shown important factors mediating the quality of attachment in institutionalised and foster care (Table 5), these include:

Age at Placement Ponciano (2013; highest quality score $86 \%$ ), found a significant correlation between age and security of attachment in a sample of Foster Care children aged 9-39 months, with younger children having higher security scores (Ponciano 2010). Similar findings were reported in BEIP: age at placement was a factor that mediated the quality of attachment, with more children placed in foster care before 24 months having secure attachments that those placed after that age. Also, the younger the children were when placed in foster care the higher the possibility of them developing an organised attachment (secure or insecure) at 42 months (Bos et al. 2011). These findings support the idea of flexibility and change in attachment at least during the first years of life.

Notably, most of the studies that reported no differences in attachment according to age at placement had samples with an age range of less than 24 months. For example, in the study conducted by Bernier et al. (2004; QA $73 \%$ ), attachment classifications of fostered children did not vary with age at placement. However, all participants in this study were infants placed with their caregivers between 6.5 and 19 months of age. Interestingly, children that were older at placement showed less proximity seeking and less contact maintenance in the Strange Situation Procedure than children placed earlier (Bernier et al. 2004). Similar findings were reported by Dozier et al. (2001) in the USA (age at placement: birth to 20 months); by Vorria et al. (2003) in a Greek study (age at placement 11-17 months); and in the Howes and Segal study conducted with 16 children aged 16-36 months old but where most were placed under 24 months old $(\mathrm{M}=18.1$, median $=16.5$ ). Therefore, there appears to be a sensitive period of the first 24 months, but with later placements potentially having a negative impact on security of attachment. 
Table 5 Factors affecting the quality of Attachment

\begin{tabular}{|c|c|c|}
\hline Factor & $\begin{array}{l}\text { Studies describing that factor is } \\
\text { related to attachment security }\end{array}$ & $\begin{array}{l}\text { Studies describing No. relation } \\
\text { to attachment security }\end{array}$ \\
\hline 1. Age at placement & $\mathbf{2}(-), 11(-)$ & $\begin{array}{l}3^{*}, 5^{*}, 6,7^{*}, \mathbf{1 3}^{*} \\
\text { *studies with all children placed } \\
\text { before } 24 \text { months }\end{array}$ \\
\hline $\begin{array}{l}\text { 2. Number of previous } \\
\text { placements }\end{array}$ & & 7 \\
\hline 3. Length of time in placement & $\begin{array}{l}7(+)^{*} \\
* \text { Indicators of good quality of care }\end{array}$ & $\begin{array}{l}13 * \\
\text { *Indicators of low quality of } \\
\text { care }\end{array}$ \\
\hline 4. Gender & $\begin{array}{l}\mathbf{2 b}-\mathbf{c}^{*}(+) \\
* \text { Girls in response to change from } \\
\text { institutional to Foster care }\end{array}$ & 13 \\
\hline 5. Genetic Factors & $\begin{array}{l}\mathbf{1}^{*} \\
\text { *In interaction with type of care }\end{array}$ & \\
\hline 6. Adoption Status & $11(+)$ & \\
\hline $\begin{array}{l}\text { 7. Contact with Biological } \\
\text { Parents }\end{array}$ & $11(-)$ & \\
\hline $\begin{array}{l}\text { 8. Organisation of Foster Home } \\
\text { and Learning Materials }\end{array}$ & $\mathbf{4 a}(+)$ & \\
\hline 9. Quality of Caregiving & $\begin{array}{l}\mathbf{2 a}(+)^{*} \\
* \text { At baseline }\end{array}$ & $\begin{array}{l}\mathbf{2} \mathbf{b}^{*} \\
* \text { At follow up, had changes in } \\
\text { caregiver }\end{array}$ \\
\hline $\begin{array}{l}\text { 10. Number of Children in Foster } \\
\text { Care Home }\end{array}$ & $11(-)$ & \\
\hline \multicolumn{3}{|l|}{ 11. Caregiver's characteristics } \\
\hline a. Sensitivity & $\begin{array}{l}\mathbf{1 1}(+), 7(+), \mathbf{4 a}(-)^{*} \\
\text { *sample of children with medical } \\
\text { fragility }\end{array}$ & $\begin{array}{l}13 * \\
\text { *Caregivers with low sensitivity } \\
\text { scores }\end{array}$ \\
\hline b. Childhood trauma & $\mathbf{4 a}(-)$ & \\
\hline c. State of Mind & $5(+)$ & \\
\hline d. Motivation & $4 b$ & \\
\hline e. Experience & $11(-)$ & \\
\hline
\end{tabular}

Numbers in bold are studies with QA $70 \%$ or more

Signs in brackets describe if the relationship between factor and attachment style is positive $(+)$ or negative $(-)$

ID number of studies according to number used in Tables 1 and 2 for each study

The exception is the Eulliet et al. (2008) study, which did not find any significant differences in attachment security according to age of placement. In this study of 36 foster children aged 3.6 to 5.6 years old (mean age at placement $=22.2$ months, $\mathrm{SD}=15.06$ ), $88 \%$ of children placed in foster care between 13 and 24 months old had secure attachments to $64 \%$ of children placed after 25 months. However, this difference did not reach statistical significance. Notably, in this study, the sample age was older and they had lived with their foster families for a longer period so other confound factors (e.g., quality of care or characteristics of caregiver) rather than age at placement, could be present and have a stronger impact on attachment security. 
Number of Previous Placements Only Howes and Segal (1993) reported on the effect of number of previous placements on quality of attachment, finding no significant effect. However, all children in this sample had at least one previous placement so no comparison could be made with children having single placements.

Length of Time in Placement Time did have a significant positive relationship with security of attachment in the Howes and Segal (1993) study so the longer children were there the more likely they were to have a secure attachment. Importantly, though, in this case the children's home was small, had very low staff turn-over and the child caregiver ratio was 3:1, all of which can be described as indicators of good quality of care. In another study, no significant differences were found regarding length of placement and attachment security; this study was conducted in a large institution described as having low quality of care (Vorria et al. 2003). Therefore, it could be hypothesized that length of placement can have a positive relationship with security on attachment in institutions that provide stability and high quality of care that may favour the formation of a secure attachment but that this does not occur in larger and more deprived institutions.

Gender No significant differences were found between gender and attachment style (secure/disorganized) by Vorria et al. (2003). However, the BEIP project in Romania found that gender could be a moderating factor to the effects of placement in foster care after institutionalisation, with girls responding in a more positive way to the change in type of placement than boys (McLaughlin et al. 2012). Specifically, boys with secure attachment did not differ at 42 months between Foster Care and Care as Usual (institutional) groups, so their attachment styles tended to be more rigid.

Genetic Moderating Factors In the one study to consider this, no significant main effect was found (Bakermans-Kranenburg et al. 2011). Although an interaction was established between the type of care (institutional vs. family) and genetic moderation factors, with a protective factor of the 5HTT/allele genotype for high scores on attachment disorganisation in institutionalized children, the authors noted that it is not clear if genetic factors can protect some children in adverse environments or if the experience of being raised in these environments can alter the expression of the gene.

Adoption Status In a study with a high quality score (86\%) conducted with a sample of foster children (Ponciano 2010), significant differences in attachment security were described between children whose foster mothers had made the decision to formally adopt them and those who did not. The children with adoption status showed higher levels of security in attachment. However, the explanation for this difference can vary widely as potentially a better relationship could have motivated the desire of adoption. No information was given about the timing and reasons for the decision to adopt the foster child (Ponciano 2010). This factor needs to be studied further as in another study the motivation for adoption was found to be negatively related to security in attachment (Cole 2005b). Furthermore, motivation for adoption and adoption status (as a decision informed to the court) are possibly different constructs that are related to attachment security in different ways.

Contact with Biological Parents In the same study by Ponciano (2010), a significant negative correlation between visits from biological parents and security of attachment was 
found, with children with fewer visits from their biological parents more likely to have a secure attachment (Ponciano 2010). We can hypothesise that, in cases of severe difficulties or maltreatment, not having contact with biological parents might facilitate the establishment of a relationship with the new carers in long-term placements. From a different perspective, another reason that may be linked with this outcomes is that contact with biological parents may discourage both the child and the foster parent to get more emotionally involved as it can place biological parent in 'first place' differing on them the main emotional link. The continuous presence of biological parents can be a remainder that AC is a temporary situation and thus, discourage emotional involvement. However, this factor needs to be studied further: in many countries Foster Care is seen as a temporal measure and contact with the biological family is encouraged as part of the Child's Rights.

Organisation of Foster Home Environment and Appropriate Learning Materials In another study with a sample of children in foster care, the organisation of foster home environment and appropriate learning materials were associated with more secure attachments (Cole 2005a, b, 2006). This can possibly be related to the capacity of the caregiver to organise the environment and provide materials according to the child's needs, also showing they are generally more responsive to children's needs.

Quality of Caregiving The BEIP study found that in institutionalised children the quality of caregiving significantly predicted the attachment rating and was associated with the quality of attachment. The 'unclassified' group (characterised by extremely low amount of attachment behaviours) had significantly lower quality of care than the other groups. However, in the 42-month follow-up, no difference in security of attachment was found in the Care as Usual group (CAUG) regarding caregiving quality (Smyke et al. 2010). This may reflect the limitation of having a single observation measure of quality of caregiving (ORCE-NICHD), particularly since some children had changes of caregiver. This is important as the ORCE-NICHD rates the observation of the child with their favourite caregiver on 5 scales (sensitivity, stimulation of development, positive regard, flat affect and detachment). Quality of Care was also assessed in the Greek study (Vorria et al. 2003). However, no associations could be made with security of attachment because all the centres (both institutions and day-care for control group) were rated as low quality. This hinders the possibility of measuring the effect of quality of care, which is a factor that has been shown to have a strong impact on attachment formation, particularly when the quality of socio-emotional interactions between Caregivers and children is considered, such as continuity, stability of caregiving and promotion of emotional involvement (St. PetersburgUSA Orphanage Team 2008).

Quality of care was also measured in the Cole study with the HOME scale (Cole 2005a, $b, 2006)$. The relationship between attachment and total environment variable approached significance ( $p=.086$ ) but, when analysed separately (i.e., organisation, learning materials and variety), only learning materials were significantly related to security in attachment. However, the association between attachment security and the general score provided by the HOME inventory that includes all the above variables and others related to quality of care, was not reported in the study.

Number of Children Living at the Foster Home In her study with Foster Children, Ponciano (2010) found a significant correlation between the number of children living in the foster home and the security of attachment in the child, with fewer children at home 
facilitating the construction of secure attachments. This is concordant with the idea of the importance of an available caregiver in the formation of a secure attachment. No other study considered this variable.

Caregiver's Characteristics Several factors related to caregiver's characteristics were studied:

The Caregiver's Sensitivity Sensitivity has been shown to be a significant factor mediating the quality of attachment both in institutionalised and foster care children. In a study carried out with 76 foster care children, foster mothers' maternal sensitivity (measured with Maternal Behavior Q-Sort) was a direct predictor of security in attachment (Ponciano 2010). In accordance with this, in a sample of children placed in a shelter with alternative caregivers, it was observed that more children formed secure attachments with the more sensitive and less detached caregivers (measured with Arnett Scale of Teacher Sensitivity; Howes and Segal 1993). The only study that found a non-significant relationship between sensitivity of the caregiver (measured with PCIS) and attachment classification (secure vs disorganised) was characterised by a sample of institutional caregivers all of whom had low levels of sensitivity defined by quality of interactions and appropriateness (Vorria et al. 2003).

Surprisingly, one of the studies considered in this review seems to point in the opposite direction. The study conducted by Cole with a sample of infants in foster care, describes that caregiver's sensitivity (specifically the score in the "involvement" sub scale of the HOME inventory) was a negative predictor for the security of attachment (Cole 2005a). This could be explained as a result of an excessive or anxious monitoring of the child, e.g., due to caregiver childhood trauma, medical fragility of children in the sample (all of them having medical records of prematurity or other factors) or the close monitoring by welfare systems. Alternatively, it could be a limitation of the use of a subscale of the HOME inventory as a single measure of caregiver's sensitivity. Further studies considering sensitivity would be useful to clarify the importance of carer's sensitivity in alternative care. All of the studies mentioned used different instruments to assess caregiver's sensitivity, which makes results difficult to compare.

Caregiver's Childhood Trauma The presence of child abuse and neglect in the Caregiver's childhood experience was related to a higher rate of insecure attachments in children placed in foster care, with infants $6 \%$ less likely to develop a secure attachment if placed with a caregiver that has experienced childhood trauma (Cole 2005a). The presence of childhood trauma was higher in kinship care than in unrelated foster care. None of the studies in institutional care considered the presence of the caregiver's childhood trauma as a variable.

Caregiver's State of Mind In a study with 50 foster mother-infant dyads, Dozier et al. (2001) found a significant association between the caregiver's state of mind and the quality of the infant's attachment with non-autonomous and dismissing foster mothers tending to have children with more disorganized patterns of attachment and the more secure and autonomous foster mothers having more secure children. This is coherent with the previously mentioned factor regarding the presence of childhood trauma which is related to unresolved status. 
Foster Caregiver's Motivation Motivation has been shown to have an effect on the security of attachment of infants in care. Specifically, two motivations are positive predictors for secure attachment (i.e., desire to increase the family size and social concern for the caregiver's specific community) and three other motivations are predictors of insecure attachment (i.e., spiritual expression, replacement of a grown child and desire of adoption; Cole 2005a, b, 2006). Possible explanations for this could be that in the first two cases there exists a more adult-centred relationship, based on the foster parents beliefs or needs and not on the infant's real needs. The desire to adopt may be a negative predictor due to the desire for a stable and life-long relationship with this child but not being sure if this would be possible or if the child could be removed from their care, thereby generating anxiety and feelings of uncertainty about the future of the relationship. However, these are hypothesises and require further study.

Foster Mother's Experience The extent of fostering and its relationship with attachment was reported in a study conducted with 76 young Foster children. No significant relationship was found between foster mother certification length and security of attachment, nor was this related to number of previous foster children. However, within this sample, the majority were experienced foster Carers, with only $11 \%$ of foster mothers having a child in care for the first time. However, when these two variables were combined in a single factor, 'less experienced mothers' were more likely to have children with a secure attachment. One possible explanation could be that having previous foster children can be linked to experiences of frustration and loss that can negatively interfere with the mother's disposition in the relationship with a new child (Ponciano 2010).

It was difficult to draw conclusions about Hypothesis 4 regarding differences in attachment styles between countries and type of institutions/foster care programs. Many differences and wide variation in rates were observed in this review. However, as several factors affect quality of attachment, it can be difficult to control confounding factors. Thus, it remains unclear whether differences are due to a) the type of $\mathrm{AC}, \mathrm{b}$ ) cultural factors or c) quality of care regardless of the type of AC. It should be noted, however, that several intervention studies have shown Quality of Care regardless of type of AC to be relevant (Lecannelier et al. 2014; McCall et al. 2010; St. Petersburg-USA Orphanage team 2008).

There are limited studies considering samples of different types of AC in the same country. Comparisons are usually made between one type of AC sample (i.e., either Institutional or Foster Care) and the normal population, who can have different histories and characteristics. Quality of care provided is often not reported. Finally, cultural factors have not been considered in previous studies and is something that may explain some of the differences between countries, but further studies are needed in this regard.

\section{Discussion}

\section{Summary of Results and Limitations}

As a whole, the studies show that attachment security can be negatively affected by the experience of alternative care and that this impact is stronger for institutional settings. However, several factors mediate the impact of the experience and not all institutions or Foster Care programs have the same outcomes for children. The mediating factors are related to characteristics of the child (age, gender, genetics and age at placement), the 
placements (type and quality) and the Carer (sensitivity, motivations and previous experience).

There are some important limitations in the studies that have been conducted on attachment in alternative care settings. One important limitation is the presence of differences in quality of care provided (i.e., size of institution, ratios, turn-over, sensitivity of caregiver) and, as this is not always measured, could be a main confounding factor. Other important factors not always considered in the studies are age at placement and previous placements.

There are also some methodological issues regarding the design of the studies that can have an impact on the rates of attachment classification. For example, in the BEIP study conducted in Romania, only $22 \%$ of children in the institutional care group (study A) had organised attachments at baseline. The other children were categorised using a 'forced classification' where a category can be assigned based on minimal displays of behaviours and even if there were no complete attachment styles. Thus, the classifications might be questioned. Notably, in the BEIP A report, at baseline not a single child in institutional care or the community sample of never-institutionalised children was classified as having a resistant style.

Another curious finding in the BEIP study (not discussed in the papers) is the dramatic reduction of disorganised attachment between baseline and 42 months in all groups (from 65.3 to $5.3-13.1 \%$ in institutional sample groups and from 22 to $9.8 \%$ in community sample). This huge difference could be due to the difference in the instruments used at each of the stages, as all the studies using the SSP with the original coding system in different settings report much higher rates of disorganised attachment than the pre-school Mac Arthur coding. However, if such a factor is not taken into account, this can affect the conclusions drawn about the impact of the Foster Care program in this study, which are based on the pre-post assessment measures.

More generally, another important aspect that has been discussed is the validity of the SSP in institutional settings in which children have experienced a variety of different caregivers and are used to them leaving (due to shifts) and, in many cases to different "strangers" being present at different moments (new caregivers, volunteers, etc.). Some authors have stated that a modified version of this instrument should be used in these settings, otherwise leading to confusions in the interpretation of children's reactions (The St. Petersburg-USA Orphanage Research Team 2008). Another way of assessing this difficulty could be the consideration of the "favourite" caregiver and the use of an attachment formation rating that can provide a better idea about the meaning of the attachment classification, placing those children with low scores on attachment formation in a more "temporary" situation that could potentially be changed if they are given the opportunity to form an attachment with their Caregiver (Bakermans-Kranenburg et al. 2011; BEIP 2005).

\section{Implications for Research}

It is important to have more longitudinal studies (although these can be difficult to conduct) and, whilst RCTs are useful, there are important ethical concerns involved. Only one study considered outcomes for Foster Care and Institutional Care together in the same country. That design should be replicated as, in some way, it controls for possible cultural factors and could make results more comparable (especially if considering a measure of quality of care). Similarly, in institutional settings, it is important to study more factors related to the Carers' characteristics as these have been more frequently studied in foster care. Such 
research could provide important information for the elaboration of public policies and international recommendations.

Contact with biological parents also requires further study to better understand influence on attachment security. Many children in foster homes or institutional care (such as Children's Homes) have regular contact with biological parents and there can be a tension between the aim of continuity in family bonds and the aim of providing good quality and stable alternative care. This factor has initially been shown to have a negative impact in attachment formation; therefore it should be further studied in order to be considered in practical recommendations.

The impact of quality of care provided in attachment security has been shown to have contradictory results, and, although it is often measured, its influence has not always been reported. Furthering understanding of the influence of QoC on attachment formation could provide important information for improvements in alternative care settings.

Finally, local research in a wider range of countries is needed. This is to consider whether there are differences in care provided by institutions and FC programs in countries other than those previously studied. The relatively small amount of research that has been conducted in less-developed countries to date (e.g., initial research in Africa) has shown cultural differences compared to Europe and the USA that are likely to be important for outcomes in children. In Latin America, no studies with a main aim of exploring attachment styles have been published, which is important to rectify. Having said that, the few studies that have indicated different characteristics of alternative care (Herreros 2009) have not necessarily been incorporated in the recent changes to public policies in that area (following the Guidelines for Alternative Care), so it is important to progress from research to policy and practice.

\section{Conclusions and Implications for Practice}

As this review shows, several factors can mediate the quality of attachment and outcomes are not always the same. These factors should be included in programs for the development of better care both in institutions and foster care with the specific aim of facilitating the development of an attachment formation (as secure as possible) between the children and their caregivers. In particular, age at placement has been shown to have a significant relation in attachment security with a cut-off point at 24 months after which attachment security decreases with age at placement. Thus, this should be considered in early intervention programs and placements decisions. Similarly, length of placement can have a positive effect if mediated by quality of care. The aim, then, should be to provide stability in high quality placements, rather than using a series of short placements with multiple changes and the inherent negative impact on attachment formation (Garcia Quiroga and Hamilton-Giachritsis 2014). Some characteristics of caregivers that go beyond the usual assessments have been shown to impact on attachment security. Thus, these factors need to be considered in the evaluation of potential foster or institutional carers, including assessments of motivations, state of mind, sensitivity, etc. Similarly, consideration of those features in a program of continuous support for carers (e.g., with opportunities to elaborate their own childhood traumas, improve their state of mind and increase their sensitivity) may improve the likelihood of a more positive, secure child-caregiver relationship.

In conclusion, placement in alternative care is not the final stage but more the beginning of a process for children. Whilst we continue to work towards having all children living in a family home, it is important to identify ways to improve outcome for those children 
remaining in alternative care. Alternative carers, whether in institutional settings or foster care, need support and guidance in the process of taking care of these especially vulnerable children. Research must take a world-wide perspective of alternative care and those working to develop policies and procedures must ensure that they take account of local cultural variations.

Open Access This article is distributed under the terms of the Creative Commons Attribution 4.0 International License (http://creativecommons.org/licenses/by/4.0/), which permits unrestricted use, distribution, and reproduction in any medium, provided you give appropriate credit to the original author(s) and the source, provide a link to the Creative Commons license, and indicate if changes were made.

\section{References}

Ainsworth, M. D. S., Blehar, M. C., Waters, E., \& Wall, S. (1978). Patterns of attachment: A psychological study of the strange situation. Hillsdale, $\mathrm{NJ}$ : Erlbaum.

Armsden, G. C., \& Greenberg, M. T. (1987). The inventory of parent and peer attachment: Individual differences and their relationship to psychological well-being in adolescence. Journal of Youth and Adolescence, 16, 427-454.

Arnett, J. (1989). Caregiver Interaction Scale. FPG Child Development Institute UNC-Chapel Hill. http:// fpg.unc.edu/sites/fpg.unc.edu/files/resources/assessments-andinstruments/SmartStart_Tool6_CIS.pdf.

Bakermans-Kranenburg, M., Dobrova-Krol, N., \& van IJzendoorn, M. (2011). Impact of institutional care on attachment disorganization and insecurity of Ukrainian pre-schoolers: Protective effect of the long variant of the serotonin transporter gene (5HTT). International Journal of Behavioral Development, 36(1), 11-18. doi:10.1177/0165025411406858.

Bayley, N. (1993). Bayley Scales of Infant Development (2nd ed.). San Antonio, TX: Psychological Corporation.

Bernier, A., Ackerman, J., \& Stovall-McClough, C. (2004). Predicting the quality of attachment relationships in foster care dyads from infants' initial behaviors upon placement. Infant Behavior \& Development, 27, 366-381. doi:10.1016/j.infbeh.2004.01.001.

Bos, K., Zeanah, C., Fox, N., Drury, S., McLaughlin, K., \& Nelson, C. (2011). Psychiatric outcomes in young children with a history of institutionalization. Harvard Review of Psychiatry, 19(1), 15-24. doi:10.3109/10673229.2011.549773.

Bowlby, J. (1979). The making and breaking of affectional bonds. London: Tavistock Publications Ltd.

Bretherton, I., Ridgeway, D., \& Cassidy, J. (1990). Assessing internal working models of the attachment relationship: An attachment story completion task for 3-year-olds. In M. Greenberg, D. Cicchetti, \& M. Cummings (Eds.), Attachment in the preschool years: Theory, research and intervention (pp. 273-308). Chicago: University of Chicago Press.

Carlson, E. (2002) Attachment formation rating. Available in Zeanah, C. H., Smyke, A. T., Koga, S. \& Carlson, E. (2005) Attachment in institutionalized and community children in Romania. Child Development, 75(5), 1015-1028.

Cassidy, J., \& Marvin, R. S. (1992) The MacArthur Attachment Working Group of the John D. and Catherine T. Attachment organization in preschool children: Procedures and coding manual, Un published coding manual. The Pennsylvania State University. MacArthur Network on the Transition from Infancy to Early Childhood.

Chisholm, K. (1998). A three year follow-up of attachment and indiscriminate friendliness in children adopted from Romanian orphanages. Child Development, 69, 1092-1106.

Cole, S. (2005a). Infants in foster care: Relational and environmental factors affecting attachment. Journal of Reproductive and Infant Psychology, 23(1), 43-61. doi:10.1080/02646830512331330947.

Cole, S. (2005b). Foster caregiver motivation and infant attachment: How do reasons for fostering affect relationships? Child and Adolescent Social Work Journal, 22(5-6), 441-457. doi:10.1007/s10560-0050021-X.

Cole, S. (2006). Building secure relationships: Attachment in kin and unrelated foster caregiver-infant relationships. Families in Society, 87(4), 498-508. doi:10.1606/1044-3894.3565.

Dozier, M., Stovall, C., Albus, K., \& Bates, B. (2001). Attachment for infants in foster care: The role of caregiver state of mind. Child Development, 72(5), 1467-1477. doi:10.1111/1467-8624.00360.

Eulliet, S., Spencer, R., Troupel-Cremel, O., Fresno, A., \& Zaouche-Gaudron, C. (2008). Les representations d'attachement des enfants accueillis et des enfants adoptes. Enfance, 1, 63-70. 
European Commission Daphne Programme. (2005). Directorate-General Justice and Home Affairs. Birmingham: University of Birmingham. ISBN 0-704-42502-5.

Farran, D., Kasari, C., Comfort, M., \& Jay, S. (1986). The Parent/Caregiver Involvement Scale training manual. Chapel Hill, NC: Frank Porter Graham Child Development Center.

Garcia Quiroga, M., \& Hamilton-Giachritsis, C. (2014). In the name of the children: Public policies for children in out of home care in Chile. Historical review, present situation and future challenges. Children and Youth Services Review, 44, 422-430. doi:10.1016/j.childyouth.2014.07.009.

George, C., Kaplan, N., \& Main, M. (1996). The adult attachment interview protocol (3rd ed.) Unpublished manuscript, University of California, Berkeley.

George, C., \& Solomon, J. (1995). Six year attachment doll play classification system. Unpublished classification manual. Oakland, CA: Mills College.

Hamilton-Giachritsis, C. E., \& Garcia Quiroga, M. (2014). Institutional care. In H. Montgomery (Ed.), Oxford online bibliographies in childhood studies. New York: Oxford University Press. doi:10.1093/ OBO/9780199791231-0098.

Harms, T., \& Clifford, R. M. (1980). Early childhood environment rating scale. New York: Teachers College Press.

Hazan, C., \& Shaver, P. R. (1987). Love conceptualised as an attachment process. Journal of Personality and Social Psychology, 52, 511-524.

Herreros, F. (2009). Attachment security of infants living in a Chilean Orphanage. Poster presented at the Biennial meeting of the Society for Research in Child Development. Denver, Co.

Howes, C., \& Segal, J. (1993). Children's relationship with alternative caregivers: The special case of maltreated children removed from their homes. Journal of Applied Developmental Psychology, 14(1), 71-81. doi:10.1016/0193-3973(93)90024-P.

Johnson, R., Browne, K., \& Hamilton-Giachritsis, C. E. (2006). Young Children in Institutional Care at Risk of Harm. Trauma, Violence \& Abuse, 7, 34-60. doi:10.1177/1524838005283696.

Katsurada, E. (2007). Attachment representations of institutionalized children in Japan. School Psychology International, 28(3), 331-345. doi:10.1177/0143034307078543.

Lecannelier, F., Silva, J. R., Hoffmann, M., Melo, R., \& Morales, R. (2014). Effects of an intervention to promote socio-emotional development in terms of attachment security: A study in early institutionalization in Chile. Infant Mental Health Journal, 35, 151-159. doi:10.1002/imhj.21436.

Main, M., Kaplan, N., \& Cassidy, J. (1985). Security in infancy, childhood and adulthood: A move to the level of representation. In Bretherton, I., \& Waters, E. (Eds.), Growing points of attachment theory and research. Monographs of the Society for Research in Child Development, Vol. 50 (1-2 serial No 209), pp. 66-104. doi:10.2307/3333827

Maluccio, A., Canali, C., \& Vecchiato, T. (2006). Family foster care: Cross-national research perspectives. Families in Society, 87(4), 491-495. doi:10.1606/1044-3894.3564.

Mapp, S. (2011). Global child welfare and well-being. Oxford: Oxford University Press.

McCall, R., Groark, C., Fish, L., Harkins, D., Serrano, G., \& Gordon, K. (2010). A socioemotional intervention in a Latin American Orphanage. Infant Mental Health Journal, 31(5), 521-542. doi:10.1002/ imhj.20270.

McCartney, K. (1996). NICHD Early Child Care Research Network. Characteristics of infant child care: Factors contributing to positive caregiving. Early Childhood Research Quarterly, 11, 269-306.

McCubbin, H. I., \& Pallerson, J. M. (1983). The famiiy stress, process: The double ABCX model of adjustment and adaptation. In H. I. McCubbin, B. Sussman, \& J. M. Patterson (Eds.), Social stress and the family (pp. 7-38). New York: The Hayworth Press Inc.

McLaughlin, K., Zeanah, C., Fox, N., \& Nelson, C. (2012). Attachment security as a mechanism linking foster care placement to improved mental health outcomes in previously institutionalized children. Journal of Child Psychology and Psychiatry, 53(1), 46-55. doi:10.1111/j.1469-7610.2011.02437.x.

Miljkovitch, R., Pierrehumbert, B., Karmaniola, A., \& Halfon, O. (2003). Les représentations d'attachement du jeune enfant. Développement d'un système de codage pour les histoires à compléter. Devenir, 15(2), 143-177. doi:10.3917/dev.032.0143.

Moore, J., \& Palacio-Quintin, E. (2001). Larticulation des attachements multiples et des stratégies de doping chez les adolescents placés en famillie daccueil. Interamerican Journal of Psychology, 35(1), 127-142.

Muadi, M., Aujoulat, I., Wintgens, A., Matonda ma Nzuzi, T., \& Pierrehumbert, B. (2012). Attachment in the abandoned children rise in residential institution in Kinshasa. Neuropsychiatrie de l'enfance et de l'adolescence, 60, 505-515. doi:10.1016/j.neurenf.2012.09.002.

NICHD. (2005). Early Child Care Research Network. Child care and child development: Results of the NICHD study of early child care and youth development. New York: Guilford. 
NICHD Early Child Care Research Network. (2006). Infant-mother attachment classification: Risk and protection in relation to changing maternal caregiving quality. Developmental Psychology, 42(1), 38-58. doi:10.1037/0012-1649.42.1.38.

Pederson, D., Moran, G., Sitko, C., Campbell, K., Ghesquire, K., \& Acton, H. (1990). Maternal sensitivity and the security of infant-mother attachment: A Q-Sort Study. Child Development, 61(6), 1974-1983. doi:10.1111/j.1467-8624.1990.tb03579.x.

Plomin, R., \& DeFries, J. C. (1985). Origins of individual differences in infancy: The Colorado Adoption Project. Orlando: Academic.

Ponciano, L. (2010). Attachment in foster care: The role of maternal sensitivity, adoption, and foster mother experience. Child and Adolescence Social Work Journal, 27, 97-114. doi:10.1007/s10560-010-0192-y.

Rutter, M., Beckett, C., Castle, J., Colvert, E., Kreppner, J., Mehta, M., et al. (2007). Effects of profound early institutional deprivation: An overview of findings from a UK longitudinal study of Romanian adoptees. European Journal of Developmental Psychology, 4(3), 332-350. doi:10.1080/ 17405620701401846.

Santelices, M. P., \& Pérez, F. (2013). Evolución del vínculo que establece el niño con el personal educativo en salas cunas chilenas. Universitas Psychologica, 12(3), 821-832.

Shechory, M., \& Sommerfeld, E. (2007). Attachment style, home leaving age and behavioural problems among residential care children. Child Psychiatry and Human Development, 37, 361-373. doi:10.1007/ s10578-007-0051-z.

Smyke, A., Dumitrescu, A., \& Zeanah, C. (2002). Attachment disturbances in young children I: The continuum of caretaking casualty. Journal of the American Academy of Child and Adolescent Psychiatry, 41, 972-982. doi:10.1097/00004583-200208000-00016).

Smyke, A. T., \& Zeanah, C. H. (1999). Disturbances of attachment interview. Unpublished manuscript. Available on the Journal's website at www.jaacap.com (via Article Plus)

Smyke, A., Zeanah, C., Fox, N., Nelson, C., \& Guthrie, D. (2010). Placement in foster care enhances the quality of attachment among young institutionalized children. Child Development, 81(1), 2012-2223. doi:10.1111/j.1467-8624.2009.01390.x.

Sroufe, L. A. (2005). Attachment and development: A prospective, longitudinal study from birth to adulthood. Attachment Human Development, 7(4), 349-367. doi:10.1080/14616730500365928.

Stovall, K. C., \& Dozier, M. (2000). The development of attachment in new relationships: Single subject analyses for 10 foster infants. Development and Psychopathology Spring, 12(2), 133-156.

The St. Petersburg-USA Orphanage Research Team. (2008). The effects of early social-emotional and relationship experience on the development of young orphanage children. Monographs of the Society for Research in Child Development, 73(3), 1-262. doi:10.1002/9781444309683.

United Nations. (2009). Guidelines for alternative care for children. United Nations General Assembly A/RES/64/142. 18 December. http://www.un.org

UNICEF. (2010). At home or in a home? Formal care and adoption for children in Eastern Europe and Central Asia. UNICEF Regional Office for Central and Eastern Europe and the Commonwealth of Independent States (CEE/CIS).

van den Dries, L., Juffer, F., van Ijzendoorn, M. H., \& Bakermans-Kranenburg, M. (2009). Fostering security? A meta-analysis of attachment in adopted children. Children and Youth Services Review, 31, 410-421.

Vorria, P., Papaligoura, Z., Dunn, J., van IJzendoorn, M., Steele, H., Kontopuolou, A., \& Sarafidou, Y. (2003). Early experiences and attachment relationships of Greek infants raised in residential group care. Journal of Child Psychology and Psychiatry, 44(8), 1208-1220. doi:10.1111/1469-7610.00202.

Waters, E., \& Deane, K. E. (1985). Defining and assessing individual differences in attachment relationships: Q-methodology and the organization of behavior in infancy and early childhood. In I. Bretherton \& E. Waters (Eds.), Growing points in attachment theory and research (pp. 41-65). Monographs of the Society for Research in Child Development, 50 (1-2, Serial No. 209).

Wells, K., \& Guo, S. (1999). Reunification and re-entry of foster children. Children and Youth Services Review, 21(4), 273-294.

Whetten, K., Ostermann, J., Whetten, R., Pence, B., ÓDonnell, K., Messer, L., et al. (2009). A comparison of wellbeing of orphans and abandoned children ages 6-12 in institutional and community-based care settings in 5 less wealthy nations. PLoS ONE, 4(12), e8169. doi:10.1371/journal.pone.0008169.

Yates, A. M., Lekies, K. S., Stockdale, D. F., \& Crase, S. J. (1997). Motivations for foster Parenting Inventory. Ames, IA: Iowa State University Research Foundation.

Zeanah, C., Smyke, A., Koga, S., \& Carlson, E. (2005). Attachment in institutionalized and community children in Romania. Child Development, 76(5), 1015-1028. doi:10.1111/j.1467-8624.2005.00894.x. 